\title{
PENGARUH BUDAYA ORGANISASI DAN IKLIM ORGANISASI TERHADAP KINERJA PEGAWAI
}

\author{
EFFECT OF ORGANIZATIONAL AND ORGANIZATIONAL CLIMATE ON \\ EMPLOYEES PERFORMANCE
}

\author{
Ely Kurniawati \\ Program Studi Akuntansi, Fakultas Ekonomi, Universitas Batam \\ elykuniawati@yahoo.co.id
}

\begin{abstract}
Abstrak
Informasi tentang hubungan antara variabel independen, yaitu budaya organisasi (x1) dan iklim organisasi (x2) dengan variabel dependen, yaitu kinerja karyawan (y) PT. Pegadaian Batam, yang merupakan seluruh karyawan PT. Pegadaian Batam yang berjumlah 168 orang. Perbedaan klasifikasi tidak diadakan didasarkan pada jenis karyawan atau status kelompok di kedua jenis sumber daya manusia. Mereka memiliki perlakuan yang sama. Sampel diambil dengan menggunakan teknik simple random sampling (pengacak sederhana). Dengan menggunakan rumus Slovin diperoleh sampel dari 63 orang. Hasil penelitian menunjukkan pengaruh positif signifikan budaya organisasi (x1) dan iklim organisasi (x2) terhadap kinerja karyawan (y) ditunjukkan oleh nilai F hitung 34.094. Nilai ini jauh lebih besar dari nilai signifikansi pertama tabel alpha 0,05 yaitu 3,15, atau $\mathrm{F}=$ $34,694 \&$ itu; f0.05 $(2: 63)=3.15$. Pola budaya tidak terbatas pada $1,27+0,629 x 1+0,315 \times 2$. Oleh karena itu, yang lebih baik adalah budaya organisasi (x1) dan iklim organisasi (x2). kinerja karyawan. Sebelumnya didasarkan pada validitas dan reliabilitas, semua instrumen validitas dan reliabilitas yang memenuhi syarat. Dan hasil penelitian ini, maka nilai R2 sebesar 0,532 diketahui. Dari nilai tersebut dapat diketahui bahwa kinerja karyawan di PT. Pegadaian Batam dipengaruhi oleh 0,430 oleh jumlah organisasi dan iklim organisasi atau jumlah menjadi 53,20\%. Itu tidak diselidiki dalam penelitian ini.
\end{abstract}

Kata kunci: Organisasi budaya, Organisasi iklim, Kinerja Pegawai

\begin{abstract}
This study aims to to gather information about the links between independent variables, namely culture organization (x1) and climate organization (x2) with a dependent variable, namely the employee performance (y) PT. Pegadaian Batam, in both singly and jointly.The population of this research is all employees of PT. Pegadaian Batam which totaled 168 people. Not held classification differences based on the type of employees or status group in this research, both types of human resources they have a equal treatment. Sample taken with using a technique simple random sampling (scrambled simple). With using formulas Slovin obtained samples from 63 people. The research results show a significant positive influence culture organization (x1) and climate organization (x2) against the employee performance (y) shown by $F$ hitung 34,094 value of. This value is far greater than in the value of the first significance $f$ tabel alpha 0.05 namely 3.15 , or $F=34,694 \&$ it; f0,05 $(2: 63)=3.15$. patterns of relationship the four variables that is expressed by the regression equation is double $=1,267+0,629 \times 1+0,315 \times 2$.Thus, the better it is the implementation of culture organization (x1) and the climate organization (x2), hence the higher also the performance of the employee. Formerly based on the validity and reliability, all the instruments qualified validity and reliability. Andfrom this research result, then the value of $r 2$ of 0,532 is known. Of the value of it can be seen that employee performance in PT. Pegadaian Batam influenced of 0,430 by the culture of the organization and climate organization or amounting to 53,20\% while the rest of 46,80\% affected by other factors that is not investigated in this study.
\end{abstract}

Keywords: Culture organization, Climate organization, Employee Performance

\section{PENDAHULUAN}

Sumber daya manusia sebagai salah satu faktor pendukung dalam suatu organisasi pada masa sekarang ini dituntut untuk memiliki kualitas dan kapabilitas yang tinggi 
seiring dengan tantangan pekerjaan yang dihadapi. Perkembangan teknologi yang pesat, persaingan bisnis yang tak terhindarkan, merupakan faktor yang mempengaruhi tuntutan akan kualitas sumber daya manusia.

Masyarakat umum meyakini bahwa sumber daya manusia yang berkualitas memegang peranan yang sangat penting dan mendasar sebagai salah satu pemacu dalam pertumbuhan berbagai kegiatan manajemen dalam hal ini difokuskan pada business management. Sumber daya manusia sebagai faktor penggerak dalam kegiatan organisasi dituntut untuk dapat mengembangkan kreativitas, inovatif, dan memiliki dedikasi tinggi yang mampu memenuhi tantangan pekerjaan yang semakin penuh persaingan dan beragam.

Kata budaya (culture) mempunyai banyak arti, budaya setiap orang berbeda dengan orang lain dan budaya akan sulit dijelaskan secara konseptual dan definitif apabila diterapkan dalam organisasi. Dengan demikian organisasi mencakup juga aspek-aspek budaya yang terwujud dalam bentuk cerita-cerita, legenda bisnis yang berhasil, nilai-nilai, dan simbolsimbol yang bermakna bagi setiap insan yang ada dalam organisasi itu.

Iklim berhubungan dengan persepsi. Hal ini berarti gambaran kondisi iklim berkaitan dengan bagaimana individu-individu menginterpretasikan peristiwa-peristiwa atau karakteristik yang dihadapi atau terjadi di lingkungan kerja organisasinya.

Berdasarkan latar belakang di atas, maka tertarik untuk mengadakan penelitian tentang" Pengaruh Budaya Organisasi Dan Iklim Organisasi Terhadap Kinerja Pegawai”

\section{Tujuan Penelitian}

1. Untuk mengetahui pengaruh budaya organisasi terhadap kinerja pegawai PT. Pegadaian (Persero) Kota Batam.

2. Untuk mengetahui pengaruh iklim organisasi terhadap kinerja pegawai PT. Pegadaian (Persero) Kota Batam.

3. Untuk mengetahui pengaruh budaya organisasi dan iklim organisasi terhadap kinerja pegawai PT. Pegadaian (Persero) Kota Batam.

\section{Manfaat Penelitian}

\section{Manfaat Teoritis}

Hasil penelitian ini juga dapat dijadikan bahan informasi yang akurat bagi para pegawai, serta bagi semua pihak yang berminat untuk memperoleh informasi dan data dasar dalam mengadakan penelitian lanjutan yang berkaitan dengan penelitian ini, terutama 
mengenai faktor-faktor lain yang berpengaruh terhadap peningkatan kinerja pegawai guna menambah khasanah ilmu pengetahuan, khususnya Manajemen Sumber Daya Manusia. Manfaat Praktis

Hasil penelitian ini diharapkan dapat bermanfaat terutama untuk para pegawai pada PT. Pegadaian (Persero) Kota Batam yaitu sebagai bahan informasi yang akurat agar selalu meningkatkan budaya organisasi dan iklim organisasi sehingga kinerja optimal dapat tercapai. Hasil penelitian ini juga dapat digunakan sebagai informasi yang penting bagi para pimpinan PT. Pegadaian (Persero) Kota Batam dalam menciptakan dinamika perkembangan mutu kinerja pegawai.

\section{Budaya Organisasi}

Kata budaya (culture) mempunyai banyak arti, budaya setiap orang berbeda dengan orang lain dan budaya akan sulit dijelaskan secara konseptual dan definitif apabila diterapkan dalam organisasi. Dengan demikian organisasi mencakup juga aspek-aspek budaya yang terwujud dalam bentuk cerita-cerita, legenda bisnis yang berhasil, nilai-nilai, dan simbolsimbol yang bermakna bagi setiap insan yang ada dalam organisasi itu.

Membicarakan masalah budaya data organisasi kita dapat mengutip pendapat Kotter dan Hasket (2005: 3) yang menyatakan bahwa variabel panting yang mempengaruhi kemajuan dan produktivitas organisasi atau perusahaan, bukan pada faktor manajemen, fungsi-fungsi penyelesaian tugas atau struktur organisasi tetapi adalah pada aspek kultural. Menurut Edward Burnet Tylor, sebagaimana dikutip oleh Taliziduhu Ndraha (2007: 43) mendefinisikan budaya dalam arti luas yang meliputi culture dan civilization adalah "culture or civilization, take its wide ethnographic sense, is that complex whole which includes knowledge, belief, art, morals, law, custom, and any other capabilities and habits acquired by man as a member of society”. Robbins (2006: 289) mendefinisikan bahwa budaya organisasi adalah suatu persepsi bersama yang dianut oleh anggota-anggota organisasi itu, suatu sistem dari makna bersama. Sementara itu Schein (2009) menjelaskan bahwa level budaya perusahaan dapat dianalisis dalam tiga kategori, yaitu: (1) Artifacts, (2) Values, dan (3) Basic Assumption.

\section{Iklim Organisasi}

Istilah iklim yang biasanya dipergunakan dalam konteks meteorology dan diartikan sebagai hawa, suhu atau cuaca suatu daerah, juga dipergunakan dalam konteks organisasi. 
Dalam konteks organisasi, makna iklim adalah keadaan atau suasana yang terdapat dalam suatu organisasi.

Beberapa ahli mengemukakan pendapatnya mengenai organisasi, antara lain : menurut McFarland yang dikutip oleh Soewarno (2005: 42), bahwa "organisasi adalah suatu kelompok manusia yang dapat dikenal yang menyumbangkan usahanya terhadap tercapainya suatu tujuan". Sedangkan Gibson, Ivancevish dan Donnelly (2007:7), yang menyebutkan bahwa "Organisasi adalah kesatuan yang memungkinkan masyarakat mencapai suatu tujuan yang tidak dapat dicapai individu secara perorangan".

Iklim berhubungan dengan persepsi. Hal ini berarti gambaran kondisi iklim berkaitan dengan bagaimana individu-individu menginterpretasikan peristiwa- peristiwa atau karakteristik yang dihadapi atau terjadi di lingkungan kerja organisasinya. Adanya perbedaan individual tentunya mempengaruhi persepsi, sehingga persepsi ini bersifat subyektif, dimana interpretasi tentang kondisi iklim bisa saja terjadi. Perbedaan ini jelas tampak antara pihak pimpinan dengan karyawan atau pimpinan dengan para karyawan dan staf administrasi lainnya. Pimpinan sebagai pelaku yang dominan dalam membentuk dan mempengaruhi iklim organisasi secara keseluruhan (baik melalui kepemimpinan maupun cara-cara yang diterapkan di dalam mengelola organisasinya), tentunya secara subyektif akan memberikan persepsi tertentu tentang iklim organisasi yang dipimpinnya. Misalnya, pimpinan akan mengatakan iklim organisasinya terbuka dengan demokratisasi kehidupan organisasi. Dilain pihak para karyawan dan staf administrasi mungkin saja menganggap iklimnya kurang terbuka.

\section{Kinerja Pegawai}

Mitrani (2005: 131) mendefinisikan kinerja sebagai pernyataan sejauh mana seseorang telah memainkan perannya dalam melaksanakan strategi organisasi, baik dalam mencapai sasaran-sasaran khusus yang berhubungan dengan peranan perseorangan, atau dengan memperlihatkan kompetensi-kompetensi yang dinyatakan relevan bagi organisasi dalam suatu peranan tertentu, atau secara lebih umum.

Rivai (2011:554) "kinerja merupakan perilaku yang nyata yang ditampilkan setiap orang sebagai prestasi kerja yang dihasilkan oleh pegawai sesuai dengan perannya dalam perusahaan".

Robbins (2007) mengemukakan "way of thinking about employee performance is a function of the interaction of ability, motivation, and oportunity ". Maksud dari definisi 
tersebut kinerja karyawan merupakan sebuah fungsi interaksi kemampuan, motivasi, dan peluang untuk berkinerja.

Aguinis (2009) mengemukakan "performance is about behavior or what employee do, not about what employee produce or the outcomes of their work' yang artinya kinerja adalah tentang perilaku atau apa yangf dilakukan oleh karyawan, bukan tentang apa yang diproduksi atau dihasilkan dari pekerjaan mereka.

\section{METODOLOGI}

Dalam meningkatkan mutu kinerja pegawai khususnya pada PT. Pegadaian (Persero) Kota Batam, maka penulis mengamati dan memperhatikan terdapat beberapa variabel yang mempengaruhinya, seperti budaya organisasi dan iklim organisasi.

\section{Hipotesis}

Hipotesis merupakan jawaban sementara terhadap rumusan masalah penelitian. Oleh karena itu rumusan masalah biasanya disusun dalam bentuk kalimat tanya. Dikatakan sementara, karena jawaban yang diberikan baru didasarkan pada teori yang relevan, belum didasarkan pada fakta-fakta empiris yang diperoleh melalui pengumpulan data (Sugiyono, 2009:93).

Berdasarkan perumusan masalah dan kerangka pikir yang telah dikemukakan, maka hipotesis penelitian ini dapat dirumuskan sebagai berikut:

1. Budaya organisasi berpengaruh signifikan terhadap kinerja pegawai PT. Pegadaian (Persero) Kota Batam.

2. Iklim organisasi berpengaruh terhadap signifikan kinerja pegawai PT. Pegadaian (Persero) Kota Batam.

3. Budaya organisasi dan iklim organisasi berpengaruh signifikan terhadap kinerja pegawai PT. Pegadaian (Persero) Kota Batam.

\section{Populasi, sampel, dan penarikan sampel}

Menurut Sugiyono (2009:80), "Populasi adalah wilayah generalisasi yang terdiri atas objek atau subjek yang memiliki kualitas dan karakteristik tertentu yang ditetapkan oleh peneliti untuk dipelajari dan kemudian ditarik kesimpulannya". Populasi dari penelitian ini adalah seluruh pegawai PT. Pegadaian (Persero) Batam yang berjumlah 168 orang dan dan menggunakan rumus slovin sehingga sampel menjadi 54 orang

Pada penelitian ini tidak diadakan klasifikasi perbedaan pegawai berdasarkan jenis atau status golongan, kedua jenis kepegawaian tersebut mempunyai perlakuan yang sama. 


\section{Teknik Analisis Data}

Teknik Analisis Data dilakukan dengan memanfaatkan komputer melalui program SPSS for windows 20.

\section{Gambaran Umum Perusahaan}

Sejarah Pegadaian dimulai pada saat pemerintah penjajahan Belanda (VOC) mendirikan Bank Van Leening yaitu lembaga keuangan yang memberikan kredit dengan sistem gadai, lembaga ini pertama kali didirikan di Batavia pada tanggal 20 Agustus 1746. Ketika Inggris mengambil alih kekuasaan Indonesia dari tangan belanda (1811-1816) Bank Van Leening milik pemerintah dibubarkan, dan masyarakat diberi keleluasaan untuk mendirikan usaha pegadaian asal mendapat lisensi dari pemerintah daerah setempat (liencentie stelsel). Namun metode tersebut berdampak buruk, pemegang lisensi menjalankan praktek rentenir atau lintah darat yang dirasakan kurang menguntungkan pemerintah berkuasa (Inggris). Oleh karena itu, metode liecentie stelsel diganti menjadi pacth stelsel yaitu pendirian Pegadaian diberikan kepada umum yang mampu membayarkan pajak yang tinggi kepda pemerintah.

Pada saat Belanda berkuasa kembali, pola atau metode pacth stelsel tetap dipertahankan dan menimbulkan dampak yang sama di mana pemegang hak ternyata banyak melakukan penyelewangan dalam menjalankan bisnisnya. Selanjutnya pemerintah Hindia Belanda menerapkan apa yang disebut dengan cultur stelsel di mana dalam kajian tentang Pegadaian, saran yang dikemukakan adalah sebaiknya kegiatan pegdaian ditangani sendiri oleh pemerintah agar dapat memberikan perlindungan dan manfaat yang lebih besar bagi masyarakat. Berdasarkan hasil penelitian tersebut, pemerintah Hindia Belanda mengeluarkan staatsblad (Stbl) No. 131 tanggal 12 Maret 1901 yang mengatur bahwa usaha Pegadaian merupakan monopoli pemerintah dan tanggal 1 April 1901 didirikan Pegadaian Negara pertama di Sukabumi (Jawa Barat), selanjutnya setiap tanggal 1 April diperingati sebagai hari ulang tahun Pegadaian.

Visi PT. Pegdaian (Persero) yaitu sebagai solusi bisnis terpadu terutama berbasis gadai yang selalu menjadi market leader dan mikro berbasis fidusia selalu menjadi yang terbaik untuk masyarakat menengah ke bawah.

Misi PT. Pegadaian (Persero) yaitu:

1. Memberikan pembiayaan yang tercepat, termudah, aman dan selalu memberikan pembinaan terhadap usaha golongan menengah ke bawah untuk mendorong 
pertumbuhan ekonomi.

2. Memastikan pemerataan pelayanan dan infrastruktur yang memberikan kemudahan dan kenyamanan di seluruh Pegadaian dalam mempersiapkan diri menjadi pemain regional dan tetap menjadi pilihan utama masyarakat.

3. Membantu pemerintah dalam meningkatkan kesejahteraan masyarakat golongan menengah ke bawah dan melaksanakan usaha lain dalam rangka optimalisasi sumber daya perusahaan.

\section{Analisis Validitas}

Uji validitas digunakan untuk mengukur sah atau valid tidaknya suatu kuesioner. Suatu kuesioner dikatakan valid jika pertanyaan pada kuesioner mampu untuk mengungkapkan sesuatu yang akan diukur oleh kuesioner tersebut (Ghozali, 2005). Hasil analisis validitas yang didistribusikan kepada 54 responden untuk tiap- tiap butir adalah sebagai berikut:

Tabel 2 Uji Validitas

\begin{tabular}{llll}
\hline Item & Nilai Korelasi & Probabilitas & Keterangan \\
\hline BO & 0.651 & 0.2480 & Valid \\
BO & 0.676 & 0.2480 & Valid \\
BO & 0.753 & 0.2480 & Valid \\
BO & 0.755 & 0.2480 & Valid \\
BO & 0.759 & 0.2480 & Valid \\
IO & 0.704 & 0.2480 & Valid \\
IO & 0.751 & 0.2480 & Valid \\
IO & 0.732 & 0.2480 & Valid \\
IO & 0.849 & 0.2480 & Valid \\
IO & 0.850 & 0.2480 & Valid \\
KP & 0.745 & 0.2480 & Valid \\
KP & 0.760 & 0.2480 & Valid \\
KP & 0.813 & 0.2480 & Valid \\
KP & 0.726 & 0.2480 & Valid \\
KP & 0.832 & 0.2480 & Valid \\
\hline
\end{tabular}

Sumber: Hasil Pengolahan Data

Berdasarkan Tabel 2, uji validitas untuk seluruh pertanyaan yang diuji menunjukkan dari ketiga variabel diperoleh semua item mempunyai korelasi skor probabilitas $r$ hasil < 0.05, sedangkan butir-butir yang gugur untuk masing-masing faktor adalah tidak ada, dengan demikian instrumen untuk Budaya Organisasi, Iklim Organisasi, dan Kinerja Pegawai memenuhi uji Validitas. 


\section{Analisis Reliabilitas}

Tabel 3

Hasil Pengujian Reliabilitas

\begin{tabular}{lll}
\hline Variabel & Alpha (a) & Status \\
\hline Budaya Organisasi & 0,654 & Reliabel \\
Iklim Organisasi & 0,763 & Reliabel \\
Kinerja Pegawai & 0,691 & Relibel \\
\hline
\end{tabular}

Sumber: Hasil Pengolahan Data

Hasil uji reabilitas tersebut menunjukkan bahwa semua variabel mempunyai koefisiean alpha yang cukup besar, yaitu diatas 0,60 sehingga dapat dikatakan semua konsep pengukur masing-masing variabel dari keusioner adalah reabilitas maka untuk selanjutnya item-item pada masing-masing konsep variabel tersebut layak digunakan sebagai alat ukur.

\section{Analisis Persamaan Regresi Linear Berganda}

Analisis regresi berganda digunakan untuk mengukur pengaruh antara budaya organisasi dan iklim organisasi terhadap peningkatan kinerja pegawai. Dengan menggunakan bantuan program SPSS 20, maka diperoleh nilai-nilai untuk regresi berganda sebagai berikut:

Tabel 4

\section{Hasil Uji Nilai Regresi}

\section{Coefficients $^{\mathrm{a}}$}

Model Unstandardized Standardized

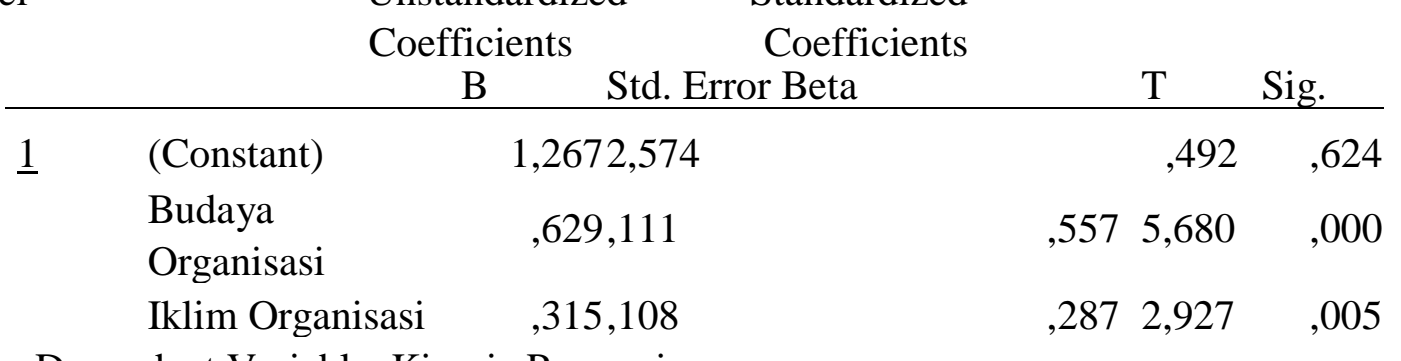

Dependent Variable: Kinerja Pegawai

Sumber: Lampiran output SPSS, 2015

Berdasarkan Tabel 4 di atas, dapat disusun persamaan regresi berganda sebagai berikut:

$\mathrm{Y}=1.267+0.629 \mathrm{X}_{1}+0.315 \mathrm{X}_{2}+\mathrm{e}$

Persamaan di atas menunjukkan bahwa ada pengaruh Budaya organisasi dan iklim organisasi terhadap kinerja karyawan PT.PEGADAIAN (Persero) Kota Batam. Dari persamaan tersebut dapat dijelaskan bahwa: Konstanta (a) sebesar 1.267 yang memberikan pengertian bahwa jika budaya organisasi dan iklim organisasi sama dengan nol (0), maka 
besarnya kinerja pegawai pada PT.PEGADAIAN (Persero) Kota Batam adalah sebesar 1.267 satuan. Sedangkan pada nilai b yang merupakan hubungan antara kinerja pegawai dengan budaya organisasi dan iklim organisasi dari variabel desentralisasi (X) sebesar 0.629 dan 0.315 yang memiliki arti bahwa jika jumlah variabel $\mathrm{X}$ bertambah $1 \%$ maka kinerja pegawai akan mengalami kenaikan sebesar 0.629 untuk budaya organisasi, dan 0.315 untuk iklim organisasi.

Dari ketiga variabel yang telah dimasukkan dan diolah datanya dalam perhitungan analisis regresi berganda pada table diketahui bahwa variabel, budaya organisasi $\left(\mathrm{X}_{1}\right)$ dan iklim organisasi $\left(\mathrm{X}_{2}\right)$ memiliki hubungan atau pengaruh dengan variabel kinerja pegawai (Y). Untuk penjelasan yang lebih detail mengenai hubungan antara variabel-variabel tersebut akan dijelaskan di dalam uji hipotesis.

$\mathrm{H}_{1}$ : budaya organisasi $\left(\mathrm{X}_{1}\right)$ berpengaruh signifikan terhadap kinerja pegawai.

Pada hipotesis pertama, $\mathrm{Hi}_{\mathrm{i}}$ dalam penelitian ini menyatakan apakah terdapat hubungan yang signifikan antara budaya organisasi dengan kinerja pegawai. Hipotesis pertama ini bisa diketahui diterima atau ditolaknya apabila nilai signifikan $\mathrm{t}$ dengan taraf signifikan atau dengan membandingkan $t_{\text {hitumg }}$ dengan $t_{\text {abel }}$, koefisien regresi tersebut signifikan jika $t_{\text {hitung }}>t_{\text {tabel }}$. Hasil pe ngujian analisis regresi signifikan $p$-value yang telah peneliti lakukan, menunjukkan bahwa pada nilai Sig. sebesar 0.000 lebih kecil dari taraf signifikan yaitu 0.05 dan pada hasil uji $\mathrm{t}$ menjelaskan bahwa $\mathrm{t}_{\text {hitung }}=5.687$ lebih besar dari $\mathrm{t}_{\text {tabel }}=1.669$. Yang memiliki arti bahwa pada variabel budaya organisasi berpengaruh signifikan terhadap variabel kinerja pegawai, atau $\mathrm{H}_{1}$ diterima.

$\mathrm{H}_{2}$ : Iklim Organisasi $\left(\mathrm{X}_{2}\right)$ berpengaruh signifikan terhadap kinerja pegawai ( $\mathrm{Y}$ ).

Pada hipotesis kedua, $\mathrm{H}_{2}$ dalam penelitian ini menyatakan apakah terdapat hubungan yang signifikan antara iklim organisasi dengan kinerja pegawai. Hipotesis kedua ini bisa diketahui diterima atau ditolaknya apabila nilai signifikan $t$ dengan taraf signifikan atau dengan membandingkan $t_{\text {hit }}$ tung dengan $t_{\text {tabel, }}$, koefisien regresi tersebut signifikan jika $t_{\text {hit }{ }_{\text {ung }}}>t_{\text {tabel. }}$. Hasil pengujian analisis regresi signifikan $p$-value yang telah peneliti lakukan, menunjukkan bahwa pada nilai Sig. sebesar 0.005 lebih kecil dari taraf signifikan yaitu 0.05 (5\%) dan pada hasil uji $t$ menjelaskan bahwa thitung $=2.927$ lebih besar dari $t_{\text {tabel }}=1.669$. Yang memiliki arti bahwa pada variabel iklim organisasi berpengaruh signifikan terhadap variabel kinerja pegawai, atau $\mathrm{H}_{2}$ diterima. 


\section{Uji F (Pengujian Hipotesis secara Simultan)}

Untuk menguji pengaruh variabel bebas secara bersama-sama diuji dengan menggunakan uji F. Hasil perhitungan regresi secara simultan diperoleh sebagai berikut:

\section{Tabel 5}

\section{Hasil Analisis Regresi Secara Simultan}

\begin{tabular}{|c|c|c|c|c|c|c|}
\hline \multicolumn{7}{|c|}{ ANOVA $^{b}$} \\
\hline \multirow{2}{*}{\multicolumn{2}{|c|}{ Model }} & \multirow{3}{*}{$\begin{array}{c}\text { Sum of } \\
\text { Squares } \\
117.145\end{array}$} & \multirow{3}{*}{$\begin{array}{l}\text { Df } \\
2\end{array}$} & \multirow{2}{*}{\multicolumn{2}{|c|}{ Mean Square F }} & \multirow{3}{*}{$\begin{array}{l}\text { Sig. } \\
, 000^{b}\end{array}$} \\
\hline & & & & & & \\
\hline 1 & Regression & & & 58.572 & 34.094 & \\
\hline & Residual & 103.078 & 60 & 1.718 & & \\
\hline & Total & 220.222 & 62 & & & \\
\hline
\end{tabular}

a. Predictors: (Constant), Budaya Organisasi dan Iklim Organisasi

b. Dependent Variable: Kinerja Pegawai Sumber: Lampiran output SPSS, 2015

Hasil Uji F yang telah dilakukan menunjukkan nilai Sig. sebesar 0.000. Nilai ini lebih kecil dari taraf signifikansi yaitu 0.05 (5\%), yang memiliki arti bahwa kedua variabel independen yaitu lingkungan kerja dan motivasi secara bersama-sama atau simultan berpengaruh signifikan terhadap variabel kinerja Pegawai, atau dengan demikian $\mathrm{H}_{3}$ diterima.

\section{Koefisien Determinasi $\left(\mathbf{R}^{2}\right)$}

Koefisien determinasi merupakan besaran yang menunjukkan besarnya variasi variabel dependen yang dapat dijelaskan oleh variabel independennya. Dengan kata lain, koefisien determinasi ini digunakan untuk mengukur seberapa jauh variabel- variabel bebas dalam menerangkan variabel terikatnya. Nilai koefisien determinasi ditentukan dengan nilai adjustedR square sebagaimana dapat dilihat pada Tabel 6.

\section{Tabel 6}

\section{Hasil Uji Nilai Koefisien Determinan}

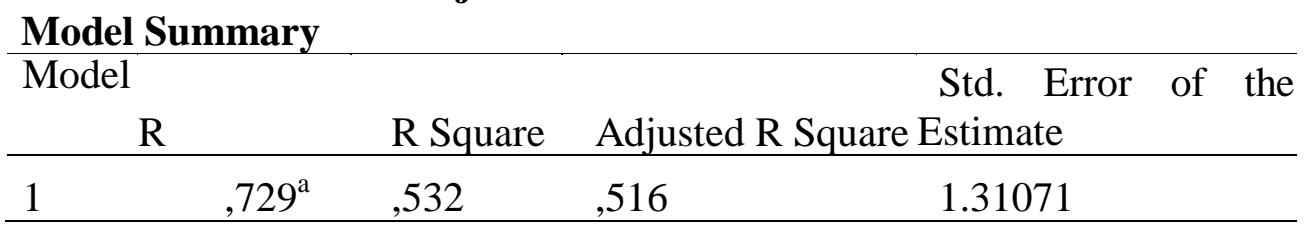

a. Predictors: (Constant), Motivasi dan Lingkungan Kerja Sumber: Lampiran output SPSS, 2015

Hasil penelitian ini, maka diketahui nilai $\mathrm{R}$ adalah sebesar 0,532. Dari nilai tersebut dapat dilihat bahwa kinerja karyawan di PT. Pegadaian Batam dipengaruhi oleh budaya organisasi dan iklim organisasi sebesar 0,430 atau sebesar 53,20\% sedangkan sisanya sebesar $46,80 \%$ dipengaruhi oleh faktor-faktor lain yang tidak diteliti dalam penelitian ini. 


\section{PEMBAHASAN}

Analisis data pada 63 pegawai PT. Pegadaian (Persero) yang menjadi Analisis data pada 63 pegawai, yang menjadi responden dalam penelitian ini diketahui 37 orang (59 \%) laki-laki dan 26 orang (41\%) perempuan, sedangkan tingkat pendidikan terakhir responden adalah Sekolah Menengah Pertama (SMA/Setara) sebanyak 34 orang (54\%) dan yang terkecil adalah S2 yaitu hanya 3 orang ( $5 \%$ ).

Berdasarkan hasil analisis diatas dapat dilihat bahwa pencarian sampel responden untuk memperoleh informasi tentang budaya organisasi dan iklim organisasi terhadap kinerja pegawai PT. Pegadaian (Persero) dapat memenuhi persyaratan data yang akurat yang mana gambaran responden menunjukkan informan yang obj ektif.

\section{Hasil Analisis Budaya Organisasi PT. Pegadaian (Persero)}

Hasil pengujian hipotesis (H1) telah membuktikan terdapat pengaruh antara budaya organisasi terhadap kinerja pegawai. Melalui hasil perhitungan yang telah dilakukan diperoleh nilai t hitung sebesar 5.680 dengan taraf signifikansi hasil sebesar 0,000 tersebut lebih kecil dari 0,05, yang berarti bahwa hipotesis dalam penelitian ini Ho ditolak dan Ha diterima. Pengujian ini secara statistik membuktikan bahwa budaya organisasi berpengaruh positif terhadap kinerja pegawai. Artinya bahwa adanya pengaruh antara variabel budaya organisasi terhadap kinerja pegawai PT. Pegadaian (Persero) Kota Batam.

\section{Hasil Analisis Iklim Organisasi PT. Pegadaian (Persero) Kota Batam}

Hasil pengujian hipotesis (H2) telah membuktikan terdapat pengaruh antara iklim organisasi terhadap kinerja pegawai. Melalui hasil perhitungan yang telah dilakukan diperoleh nilai t hitung sebesar 2.927 dengan taraf signifikansi hasil sebesar 0,005 tersebut lebih kecil dari 0,05, yang berarti bahwa hipotesis dalam penelitian ini Ho ditolak dan Ha diterima. Apabila angka probabilitas signifikansi > 0,05, maka Ho ditolak dan Ha diterima. Pengujian ini secara statistik membuktikan bahwa iklim organisasi berpengaruh positif terhadap kinerja pegawai. Artinya bahwa adanya pengaruh antara variabel iklim organisasi terhadap kinerja pegawai PT. Pegadaian (Persero) Kota Batam. Hasil penelitian ini mendukung hasil penelitian Ratnasari dan Sutjahjo (2017) yang menyatakan bahwa iklim organisasi berpengaruh signifikan terhadap kinerja karyawan. 


\section{KESIMPULAN DAN SARAN}

\section{Kesimpulan}

Hasil pengujian hipotesis menunjukkan bahwa ketiga hipotesis alternatif $\left(\mathrm{H}_{\mathrm{a}}\right)$ yang diajukan dalam penelitian ini diterima, dan menolak hipotesis nol $\left(\mathrm{H}_{0}\right)$. Beberapa kesimpulan penelitian dapat dirumuskan sebagai berikut:

Pertama, terdapat pengaruh positif yang signifikan antara budaya organisasi terhadap kinerja karyawan pada PT. Pegadaian Persero Kota Batam. Dengan demikian berarti makin baik budaya organisasi dalam suatu perusahaan, maka makin tinggi juga kinerja pegawai tersebut. Demikian pula sebaliknya, makin buruk budaya organisasi diterapkan dalam suatu perusahaan, makin menurun pula kinerja karyawan tersebut. Oleh karena itu penulis menganggap bahwa dalam mencapai tingkat produktivitas yang tinggi hendaknya PT. Pegadaian (Persero) Batam memiliki konsep budaya organisasi yang terarah, jelas, mengakar di setiap jiwa pegawai dan budaya organisasi harus di evaluasi terus setiap tahun untuk disesuaikan dengan visi misi perusahaan apakah masih sejalan atau perlu dilakukan berbagai revisi strategis.

Kedua, terdapat pengaruh positif yang signifikan iklim organisasi terhadap kinerja pegawai pada PT. Pegadaian (Persero) Batam. Dengan demikian berarti makin membaik penciptaan iklim organisasi tempat pegawai bekerja, maka semakin tinggi juga mutu kinerja pegawai tersebut. Demikian pula sebaliknya makin kurang baik pelaksanaan iklim organisasi tempat pegawai bekerja, maka semakin rendah juga mutu kinerja pegawai tersebut. Oleh karena itu iklim organisasi merupakan variabel yang penting untuk diperhatikan dalam memprediksi mutu kinerja pegawai.

Ketiga, terdapat pengaruh positif yang signifikan budaya organisasi dan iklim organisasi terhadap kinerja pegawai pada PT. Pegadaian (Persero) Batam. Dengan demikian berarti makin baik penjiwaan budaya organisasi dan makin kondusif iklim orrganisasi, maka makin tinggi juga mutu kinerja pegawai tersebut. Demikian pula sebaliknya, makin kurang baik budaya organisasi, dan makin rendah pemahaman akan iklim organisasi, maka makin rendah juga mutu kinerja pegawai tersebut. Oleh karena itu budaya organisasi, dan iklim organisasi merupakan variabel yang penting untuk diperhatikan dalam memprediksi kinerja pegawai. 


\section{Saran}

Berdasarkan kesimpulan yang telah dikemukakan di atas, maka diajukan beberapa saran sehubungan dengan upaya meningkatkan pemahaman akan budaya organisasi dan iklim organisasi dalam rangka meningkatkan mutu kinerja pegawai. Saran-saran tersebut dapat dikemukakan sebagai berikut :

Pertama, bagi pimpinan PT. Pegadaian (Persero) Batam untuk lebih meningkatkan kualitas budaya organisasi pada pegawai agar pegawai bekerja dengan sungguh-sungguh. Pegawai yang bekerja dengan budaya organisasi yang baik akan menghasilkan prestasi yang menggembirakan. PT. Pegadaian (Persero) Batam sebagai organisasi yang melayani masyarakat di Kota Batam agar dapat melakukan upaya peningkatan mutu kinerja pegawai dengan cara meningkatkan penjiwaan dan pelaksanaan budaya organisasi dari hal-hal yang paling mudah sampai dengan hal-hal yang paling berat dilakukan. Organisasi juga perlu meningkatkan kualitas sumber daya manusia yang terdiri dari pegawai agar mampu meningkatkan kualitas hasil kerjanya.

Kedua, PT. Pegadaian (Persero) Batam sebaiknya mengadakan kegiatan- kegiatan yang dapat meningkatkan efektivitas komunikasi seperti melalui rapat-rapat yang melibatkan juga pegawai di level bawah, kegiatan-kegiatan informal, dan penyediaan media komunikasi, dan lain sebagainya. Dalam rangka menemukan pola gaya kepemimpinan yang tepat pada PT. Pegadaian (Persero) Kota Batam maka diperlukan pengetahuan dan pemahaman lebih lanjut mengenai bidang psikologi dan atau perilaku organisasi.

Ketiga, Kepada pimpinan PT. Pegadaian (Persero) Kota Batam diharapkan untuk selalu memberikan dorongan kepada pegawainya dalam melaksanakan pekerjaan sesuai dengan tugas dan tanggung jawabnya masing-masing karena dinilai oleh pegawai pimpinan kurang memberikan dukungan.

Keempat, Kepada pimpinan untuk dapat menerima ide-ide baru dalam menyelesaikan tugas oleh pegawai karena ide-ide baru yang disampaikan dapat memberikan inovasi baru perusahaan dalam meningkatkan kinerja pegawai.

Kelima, perlunya peningkatkan perhatian dan kebijakan terhadap disiplin kerja bagi pegawai hal ini didukung bahwa disiplin kerja merupakan kebutuhan bagi pegawai saat ini, dengan membuat peraturan-peraturan yang transparan. Sehingga diharapkan mampu mendorong setiap pegawai agar menyadari bahwa ada jaminan karier bagi siapa saja yang berkemauan dan mempunyai kemampuan kerja yang tinggi. 
Keenam, penelitian ini masih dapat dikembangkan dengan penelitian lain dengan mengubah atau menambah variabel bebasnya, sehingga dapat diketahui faktor-faktor lain yang juga mempengaruhi secara signifikan terhadap prestasi kerja.

\section{REFERENSI}

Anastasi, Anne (2009), Manajemen Personalia dan Sumber Daya Manusia, Bandung: Penerbit Ganesha.

Edi, Agung Wibowo (2013), Aplikasi Praktis SPSS Dalam Penelitian, Yogyakarta : Penerbit Gava Media.

Indrawijaya, Adam Ibrahim, (2010), Teori, Perilaku dan Budaya Organisasi, Bandung : PT. Refika Aditama.

Izhar, Raja (2014), Pengaruh Budaya Organisasi, Iklim Organisasi dan Gaya Kepemimpinan Terhadap Mutu Kinerja Karyawan Pada PT. Calfarme Hygiene, STIE Ibnu Sina, Batam.

Komarrudin (2007), Tata Kelola Perkantoran dan Kepegawaian, Jilid I, Cetakan V, Jakarta: Penerbit Bina Pustaka.

Maksum, Ali (2014). Pengaruh Supervisi Pimpinan, Budaya Organisasi dan Tanggung Jawab Kerja Terhadap Mutu Kinerja Pegawai Pada Bank OCBC Cabang Pekanbaru, Skripsi, Universitas Riau, Pekanbaru.

Ratnasari, Sri Langgeng dan Gandhi Sutjahjo. 2017. Kompensasi, Iklim Organisasi, Dan Kepuasan Kerja Terhadap Kinerja Karyawan PT. PEB. Jurnal Mebis: Manajemen dan Bisnis, Vol. 2 (2), 2017. ISSN: 2599-283X (Online) ISSN: 2528-2433 (Cetak) http://mebis.upnjatim.ac.id/index.php/mebis/article/view/14/1. Hal 71-75.

Robbins, Stephen P. (2006). Organizational Behavior: Concept, Controversies and Application,, Englewood Cliff : Prentice Hall.

Simamora, Bilson (2009), Manajemen Pengawasan dan Implikasinya, Edisi II, Penerbit BPFE, UI, Jakarta.

Sobirin, Achmad, (2009), Budaya Organisasi, Edisi Kedua, Cetakan Pertama, Yogyakarta, UPP STIM YKPN.

Suzaidar (2014), Pengaruh Harga Diri, Iklim Organisasi, Komunikasi dan Disiplin Kerja Terhadap Kinerja Pegawai Pada Badan Kominfo Kota Batam, Skripsi, STIE Ibnu Sina, Batam. 
Sunyoto, Danang, (2013), Teori, Kuesioner dan Proses Analisa Data Perilaku Organisasional, Yogyakarta : Center for Academic Publishing Service.

Sugiyono, (2008), Metodologi Penelitian Untuk Ekonomi, Yogyakarta : Penerbit CAPS.

Syofyardi, (2010), Statistik Ilmu Ekonomi, Fakultas Ekonomi, Universitas Andalas, Padang.

Taliziduhu, Ndraha (2007), Pengantar Manajemen Pengawasan dan Tata Kelola, Edisi 2, Jakarta : Penerbit Rajawali.

Torang, Syamsir, (2013), Organisasi dan Manajemen, Bandung: Penerbit Alfabeta.

Wianarto Suryolaksmono (2008), Manajemen Pengawasan Kinerja, Edisi Revisi. Bandung: Penerbit Transito.

Wahyudin dan Muryati (2010), Faktor-Faktor Yang Mempengaruhi Kepuasan Pelanggan, Yogyakarta: Penerbit Andi. 